\title{
Helminthes and protozoan of farmed pirarucu (Arapaima gigas) in eastern Amazon and host-parasite relationship
}

\author{
[Helmintos e protozoários de pirarucu (Arapaima gigas) cultivado na Amazônia oriental, \\ e relação hospedeiro-parasito] \\ R.G.B. Marinho ${ }^{1,2}$, M. Tavares-Dias ${ }^{1 *}$, M.K.R. Dias-Grigório ${ }^{1,2}$, L.R. Neves ${ }^{1}$, E.T.O. Yoshioka ${ }^{1}$, \\ C.L. Boijink ${ }^{3}$, R.M. Takemoto ${ }^{4}$ \\ ${ }^{1}$ Embrapa Amapá - Macapá, AP \\ ${ }^{2}$ Pós-graduação - Universidade Federal do Amapá (Unifap) - Macapá, AP \\ ${ }^{3}$ Embrapa Amazônia Ocidental - Manaus, AM \\ ${ }^{4}$ Universidade Estadual de Maringá (UEM) - Maringá, PR
}

\begin{abstract}
The parasitofauna in the giant Amazon basin, pirarucu (Arapaima gigas Schinz, 1822) cultured in fish farms from the state of Amapá, in eastern Amazonia (Brazil) was investigated. Of the 100 examined fish, 90.0\% were parasitized by Ichthyophthirius multifiliis (Ciliophora), Dawestrema cycloancistrium, Dawestrema cycloancistrioides (Monogenoidea) and Polyacanthorhynchus macrorhynchus (Acanthocephala), which had an aggregated distribution pattern. The highest infection rates were caused by I. multifiliis and the lowest by P. macrorhynchus. Infection rates were different for each fish farm, due to different water quality and management characteristics. A negative correlation was found between the intensity of monogenoideans D. cycloancistrium and D. cycloancistrioides and the relative condition factor $(\mathrm{Kn})$, but the welfare of fish was not affected by parasitism. The number of I. multifiliis was positively correlated with the weight and total length of hosts, while the intensity of monogenoideans was negatively correlated with body weight and total length. This study is the first to record the occurrence of P. macrorhynchus in A. gigas farmed in Amazon.
\end{abstract}

Keywords: Amazonia, fish farm, freshwater fish, parasites, sanity

\section{RESUMO}

Investigou-se a parasitofauna no gigante da bacia amazônica, pirarucu (Arapaima gigas Schinz, 1822), cultivado em pisciculturas do estado do Amapá, na Amazônia oriental, Brasil. Dos peixes examinados, 90,0\% estavam parasitados por Ichthyophthirius multifiliis (Ciliophora), Dawestrema cycloancistrium, D. cycloancistrioides (Monogenoidea) e Polyacanthorhynchus macrorhynchus (Acanthocephala), os quais tiveram um padrão de distribuição agregado. As maiores taxas de infecção foram causadas por I. multifiliis, e as menores por P. macrorhynchus. As pisciculturas examinadas apresentaram diferentes taxas de infecção devido às diferentes características de qualidade de água e de manejo. Houve correlação negativa entre a intensidade de monogenoideas e o fator de condição relativo (Kn), mas a saúde dos peixes não foi afetada pelo parasitismo. A intensidade de I. multifiliis foi positivamente correlacionada com o peso e o comprimento, enquanto a intensidade de monogenoideas $\mathrm{D}$. cycloancistrium $e$ D. cycloancistrioides mostrou correlação negativa com o peso e o comprimento total dos hospedeiros. Este estudo foi o primeiro registro da ocorrência de P. macrorhynchus em A. gigas cultivados na Amazônia.

Palavras-chave: Amazônia, piscicultura, peixe de água doce, parasitos, sanidade

Recebido em 7 de novembro de 2011

Aceito em 7 de fevereiro de 2013

*Autor para correspondência (corresponding author)

E-mail:marcos.tavares@embrapa.br 


\section{INTRODUCTION}

In the giant Amazon basin, pirarucu (Arapaima gigas, Arapaimidae, Osteoglossiformes), is the largest scaled freshwater fish species in world; it can reach three meters of length (Araújo et al., 2009a; Pereira-Filho and Roubach, 2010; Núñez et al., 2011) and weight up to $200 \mathrm{~kg}$ (PortesSantos et al., 2008; Araújo et al., 2009a). This fish is a source of income for several riverine communities from Amazonia who live from extractive fishing. Hence, natural pirarucu populations have been subjected to excessive fishing for human food and ornamental fish trading. However, this fish very attractive for Amazon aquaculture due to its many advantages (Núñez et al., 2011).

Pirarucu A. gigas is a carnivorous fish that accepts an artificial diet when properly trained. Its aerial breathing facilitates cultivation in waters with low availability of dissolved oxygen, which is not possible for gill breathing fish. It has a high growth rate, reaching $7-10 \mathrm{~kg}$ in 12 months of farming. In addition, this fish tolerates rough handling, high stocking densities and presents good zoo technical indexes when in captivity (Ono et al., 2003; Ono et al., 2004; Pereira-Filho and Roubach, 2010; Núñez et al., 2011). These positive factors have encouraged the culture of this Amazonian fish in Brazil, which closed 2010 with a production of 10.4 tons (MPA, 2012). There are few studies on the epidemiology of parasites for this fish cultured in other regions from Amazon, including the State of Amapá, in eastern Amazon. However, Brazilian aquaculture has reported parasitic infection data in other finfish.

A recent survey noticed that $A$. gigas has a high parasite diversity in the natural environment, including one Myxozoa specie, three Monogenoidea, nine Nematoda, two Cestoda, three Digenea, three Crustacea, two Acanthocephala and one Pentastomida species (Araújo et al., 2009a). Most of these studies are taxonomic descriptions, but there are few epidemiological reports for cultured A. gigas.

In fish farms from the State of Amazonas, in central Amazon, A. gigas infection by Dawestrema cycloancistrium and Dawestrema cycloancistrioides (Monogenoidea), and Trichodina sp. (Protozoa) were the most prevalent. In addition, infection by crustacean Argulus sp., protozoan Ichthyobodo, nematodes Goezia spinulosa, Terranova serrata and Camallanus tridentatus (Araújo et al., 2009a,b) were also reported. Therefore, fish farming is not without its problems, and these include disease outbreaks and the consequences of introducing parasites to new hosts and/or new locations with the transportation of live fish. Hence, severe epizootics can occur and cause economic losses to fish farmers.

The knowledge of the ecological relationships among parasites, their hosts and the environment in which they live is extremely important to avoid significant economic losses (Lizama et al., 2007a, b). Therefore, a concern for researchers has been to broaden the knowledge about the strategies used by different parasites and their hosts in such confined environments. This information, besides explaining the presence or absence of certain parasites and the rates of parasitism (Pavanelli et al., 2004; Takemoto et al., 2009; Eiras et al., 2010), may also assist in the proper use of management techniques leading to improvements in water quality. Thus, these techniques improve the quality of fish, the ultimate goal of all fish farms (Lizama et al., $2007 b$ ). For this reason, the aim of this study was to investigate the diversity of parasites in $A$. gigas from three fish farms in Macapá, State of Amapá, Brazil (in eastern Amazon), and their relationship to this host.

\section{MATERIAL AND METHODS}

In three fish farms from the municipality of Macapá, State of Amapá, in the eastern Amazon, Arapaima gigas fingerlings weighting on average $15 \mathrm{~g}$, were fed with a homogeneous mixture of zooplankton, minced fish meat, mineral and vitamin premix and extruded commercial ration with $46 \%$ crude protein (Ono, 2003; Ono, 2004) during the food training. After the training, the fish were fed from four to six times daily exclusively with a commercial ration containing $46 \%$ crude protein. During the growing period, these fish were fed twice daily with a commercial ration containing $40 \%$ crude protein. From October 2009 to September 2010, young fish (Table 1) were collected in three fish farms (named WR, PE and LM) and necropsied for parasitological analyses. 
Table 1. Collection sites, pond sizes and Arapaima gigas age from three fish farms in eastern Amazon, Brazil

\begin{tabular}{cccc}
\hline Fish farm & Geographical location & Pond size $\left(\mathrm{m}^{3}\right)$ & Age (months) \\
\hline WR & S: $0^{\circ} 02^{\prime} 31.4^{\prime \prime}-\mathrm{W}: 051^{\circ} 07^{\prime} 34.4^{\prime \prime}$ & 10,000 & $24-33$ \\
LM & S: $0^{\circ} 00^{\prime} 1.35^{\prime \prime}-\mathrm{W}: 051^{\circ} 06^{\prime} 12,8^{\prime \prime}$ & 1,800 & 18 \\
PE & N: $0^{\circ} 00^{\prime} 04.5 .4^{\prime \prime}-\mathrm{W}: 051^{\circ} 05^{\prime} 52.1^{\prime \prime}$ & 2,000 & $13-15$ \\
\hline
\end{tabular}

All fish were weighted $(\mathrm{kg})$, measured in length $(\mathrm{cm})$ and necropsied for parasite analyses. Their gills and gastrointestinal tract were examined. These organs were removed and analyzed with the aid of a common light microscope and a stereomicroscope, respectively. The methodology used for collection, fixation (Eiras et al., 2006; Thatcher, 2006) and quantification of parasites (Tavares-Dias et al., 2001a, b) followed previous recommendations. The identification of the collected parasites was according to Baylis (1927), Machado-Filho (1947), Kritsky et al. (1985) and Thatcher (2006). After these procedures, parasitological indexes were calculated for evaluation of the levels of infection according to the recommendations of Rohde et al. (1995) and Bush et al. (1997). The index of dispersion (ID) and discrepancy index (D) were employed to detect distribution patterns of the parasites infracommunity (Rózsa et al., 2000), for species with prevalence $\geq 10 \%$.
The length and weight of the hosts were used to calculate the relative condition factor $(\mathrm{Kn})$ of parasitized and non-parasitized fish according to Le-Cren (1951). Spearman's rank correlation coefficient $(r s)$ was used to determine the possible correlations between the total length of the host and the number of parasites, and also to verify correlations between the intensity of monogenoideans and the relative condition factor (Zar, 1999).

The potential of hydrogen $(\mathrm{pH})$, temperature $\left(\mathrm{T}^{\mathrm{O}} \mathrm{C}\right)$ and levels of dissolved oxygen (DO) of the ponds were measured using digital devices suitable for each purpose

\section{RESULTS}

All the water quality parameters that were monitored showed similar values for the three fish farms, except the levels of dissolved oxygen which were lower in LM fish farm (Figure 1). In addition, the pond in this fish farm also showed high eutrophication levels.

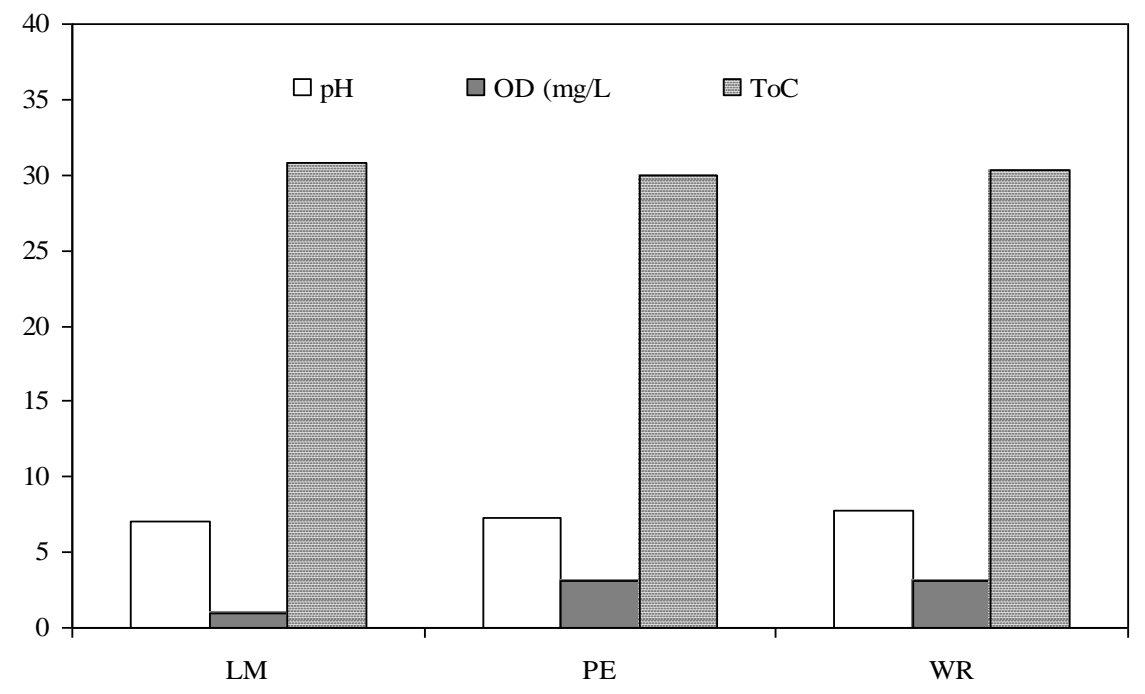

Figure 1. Mean values of water quality in ponds of farmed Arapaima gigas in eastern Amazon, Brazil. WR, PE and LM: Fish farm. 
A total of 100 specimens of A. gigas were examined in the three fish farms, of which $95.0 \%$ were parasitized; there were no differences among the prevalence levels (Table 2). They showed one or more parasites such as Ichthyophthirius multifiliis Fouquet, 1876 (Protozoa: Ciliophora); Dawestrema cycloancistrium Price and Nowlin, 1967 and D. cycloancistrioides Kritsky, Boeger and Thatcher, 1985 (Monogenoidea: Dactylogyridae) and Polyacanthorhynchus macrorhynchus Diesing, 1856 (Acanthocephala: Polyacanthorhynchidae).

Table 2. Mean values \pm standard deviation of body weight and total length for Arapaima gigas from three fish farms in eastern Amazon, Brazil

\begin{tabular}{cccccc}
\hline Fish farm & Weight $(\mathrm{kg})$ & Total length $(\mathrm{m})$ & EF & PF & P $(\%)$ \\
WR & $24.760 \pm 3.49$ & $1.44 \pm 0.07$ & 20 & 19 & 95.0 \\
PE & $14.220 \pm 2.59$ & $1.17 \pm 0.06$ & 40 & 40 & 100 \\
LM & $12.700 \pm 2.17$ & $1.10 \pm 0.04$ & 40 & 36 & 90.0 \\
Total & - & - & 100 & 95 & 95.0 \\
\hline
\end{tabular}

EF: Examined fish; PF: Parasitized fish; P: Prevalence.

Table 3. Parasitological indexes of Ichthyophthirius multifiliis for Arapaima gigas from three fish farms in eastern Amazon, Brazil

\begin{tabular}{lccc}
\hline & WR & PE & LM \\
\hline Examined fish & 20 & 40 & 40 \\
Parasitized fish & 14 & 40 & 36 \\
Prevalence (\%) & 70.0 & 100 & 90.0 \\
Mean intensity & 482,728 & $221,999.3$ & $6,841.051$ \\
Mean abundance & $337,909.6$ & $221,999.3$ & $352,426.8$ \\
Range of intensity & $36,557-1,034.796$ & $39,889-393,120$ & $41,300-373,670$ \\
Total number of parasites & $6,758.192$ & $8,879.973$ & $14,097.072$ \\
\hline
\end{tabular}

WR, PE and LM: Fish farm.

The highest mean intensity by I. multifiliis on the gills of A. gigas occurred in the LM fish farm and the lowest one in PE fish farm; however, in last one the prevalence was of $100 \%$ (Table 3 ). In the gills, parasitism by monogenoideans $D$. cycloancistrium and D. cycloancistrioides was highest in PE fish farm and lowest in WR fish farm; however, these parasites were not found in fish from LM fish farm. In the intestines of $A$. gigas, infection by $P$. macrorhynchus occurred only in the WR fish farm (Table 4).

Table 4. Parasitological indexes of helminthes monogenoideans (Dawestrema cycloancistrium and D. cycloancistrioides) and acanthocephalans for Arapaima gigas from three fish farms in eastern Amazon, Brazil

\begin{tabular}{lccc}
\hline \multirow{2}{*}{ Parasite } & \multicolumn{2}{c}{ Dawestrema spp. } & $\begin{array}{c}\text { Polyacanthorhynchus } \\
\text { macrorhynchus }\end{array}$ \\
\cline { 2 - 4 } & WR & PE & WR \\
\hline Examined fish & 20 & 40 & 20 \\
Parasitized fish & 14 & 40 & 19 \\
Prevalence (\%) & 70.0 & 100 & 95.0 \\
Mean intensity & 57.3 & 214.7 & 28.2 \\
Mean abundance & 40.1 & 214.7 & 26.7 \\
Range of intensity & $26-131$ & $110-371$ & $3-118$ \\
Total number of parasites & 802 & 8.589 & 535 \\
\hline
\end{tabular}

WR, PE and LM: Fish farm. 
I. multifiliis was the parasite with the highest mean relative dominance and $P$. macrorhynchus the one with the lowest mean relative dominance (Table 5). Parasites infracommunity showed a typical aggregated distribution pattern, with the higher values of aggregation in Dawestrema spp. and P. macrorhynchus (Table 6).

Table 5. Parasitological indexes for pirarucu Arapaima gigas $(\mathrm{n}=100)$ from three fish farms in eastern Amazon, Brazil

\begin{tabular}{lccccc}
\hline Parasite & $\mathrm{P}(\%)$ & $\mathrm{MI} \pm \mathrm{SD}$ & $\mathrm{MA}$ & $\mathrm{TNP}$ & $\mathrm{RD}$ \\
\hline Ichthyophthirius multifiliis & 90.0 & $249,769.0 \pm 166,809.2$ & $224,792.2$ & $22,479.216$ & 0.99955 \\
Dawestrema spp. & 54.0 & $173.9 \pm 89.0$ & 93.9 & 9.391 & 0.00042 \\
Polyacanthorhynchus & 19.0 & $28.1 \pm 32.6$ & 53.5 & 535 & 0.00002
\end{tabular}

macrorhynchus

P: Prevalence; MI: Mean intensity; Standard Deviation; TNP: total number of parasites; MA: Mean abundance; RD: Relative dominance.

Table 6. Dispersion index (DI), $d$ statistic and discrepancy index (D) for the parasites of Arapaima gigas in fish farms from the eastern Amazon, Brazil

\begin{tabular}{lccc}
\hline Parasite & DI & $d$ & D \\
\hline Ichthyophthirius multifiliis & 6.332 & 10164.3 & 0.379 \\
Dawestrema spp. & 8.556 & 263.8 & 0.641 \\
Polyacanthorhynchus macrorhynchus & 3.701 & 30.2 & 0.866 \\
\hline
\end{tabular}

There was no significant $(\mathrm{P}=0.998)$ difference in the relative condition factor of parasitized $(\mathrm{Kn}=1.00 \pm 0.02)$ and non-parasitized fish $(\mathrm{Kn}=$ $1.00 \pm 0.002)$, but a significant negative correlation was found between the number of monogenoideans and the relative condition factor (Kn) of the hosts (Fig. 2). In addition, there was a significant positive correlation between the number of I. multifilis and the total length and body weight of the hosts (Fig. 3), as well as a negative correlation between the number of monogenoideans and the total length and body weight (Fig. 4). No correlation between the number of $P$. macrorhynchus and the total length ( $r s=-0.0776, \mathrm{P}=0.748)$ and body weight $(r s=-$ $0.0430, \mathrm{P}=0.854$ ) of A. gigas was found.

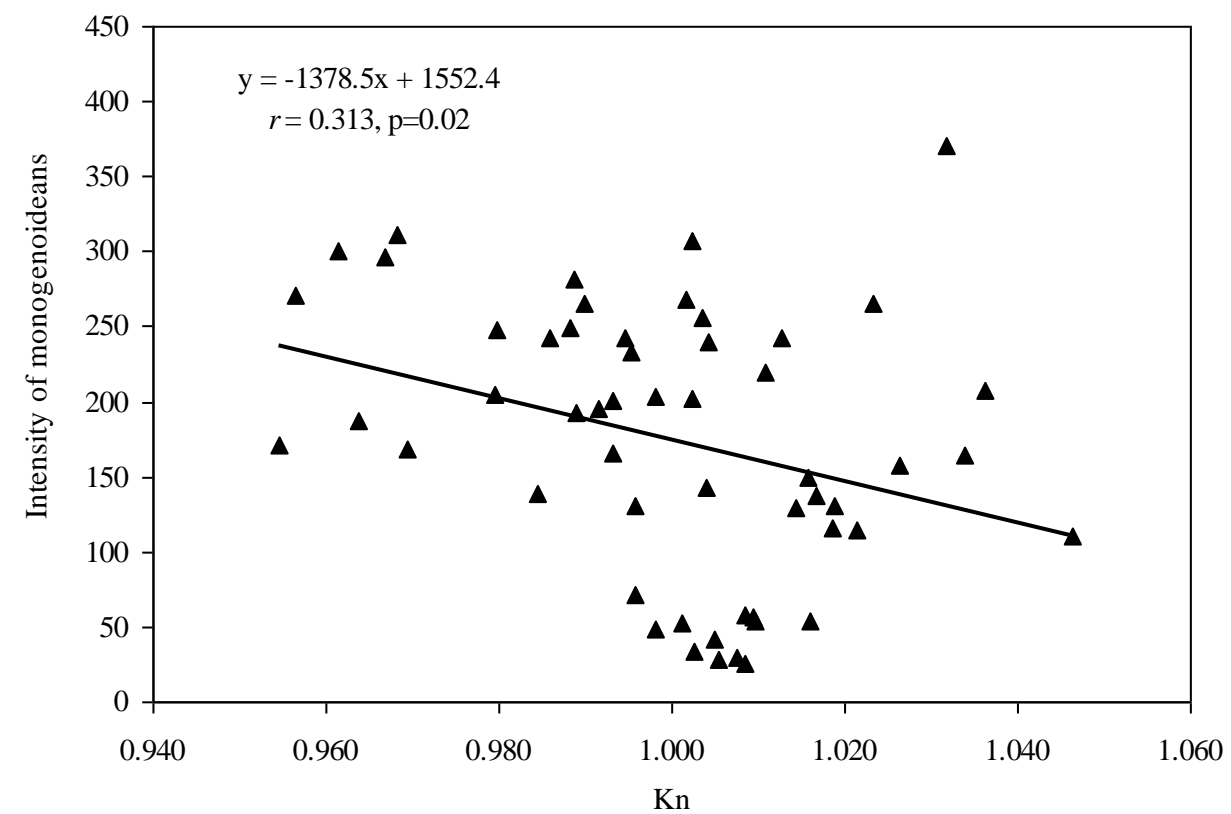

Figure 2. Correlation between Kn and intensity of monogenoideans (Dawestrema cycloancistrium and D. cycloancistrioides) in Arapaima gigas gills (n=54) from eastern Amazon, Brazil. 

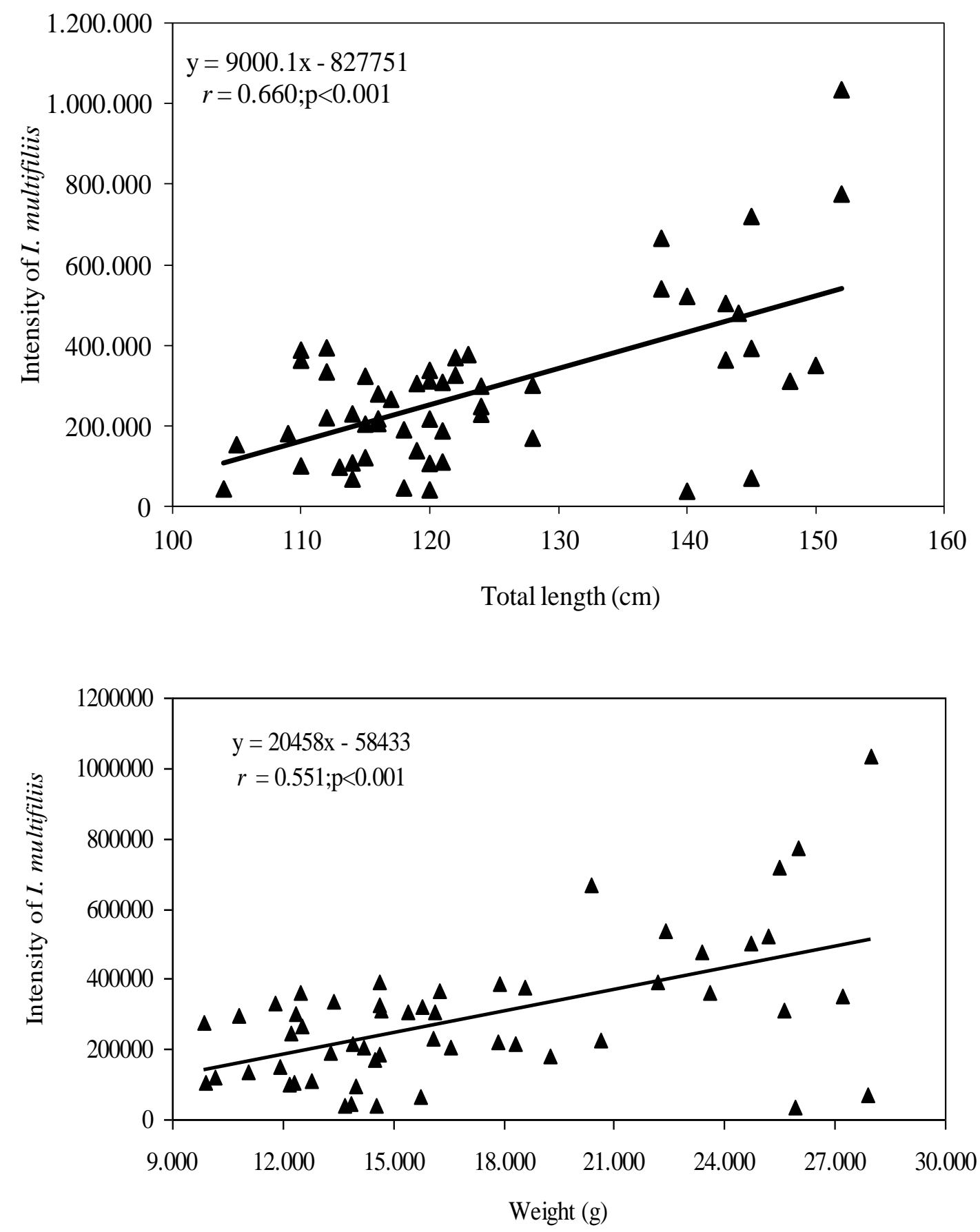

Figure 3. Correlation between the intensity of Ichthyophthirius multifiliis and body weight and length of Arapaima gigas $(\mathrm{n}=54)$ in fish farms from the eastern Amazon, Brazil. 

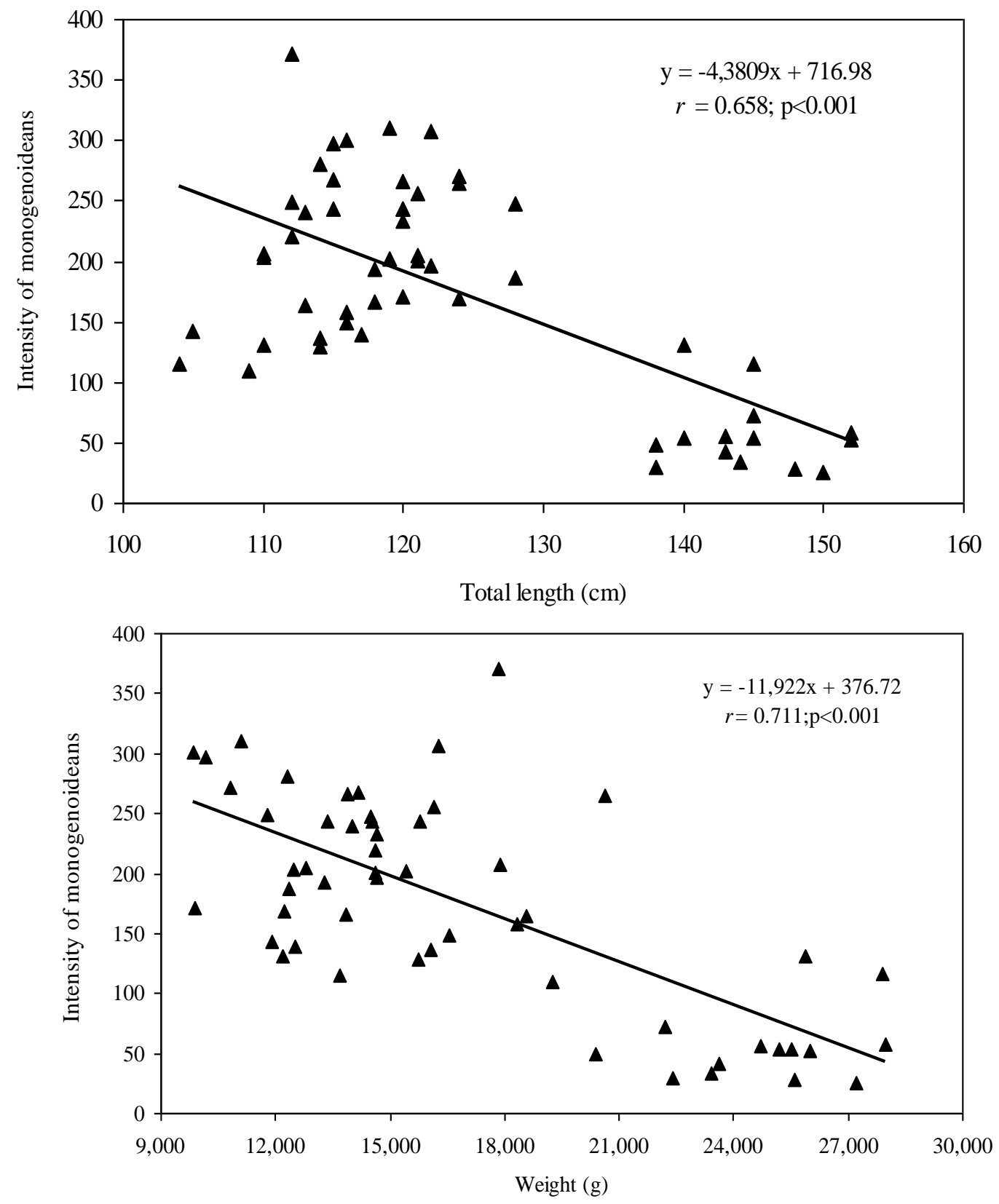

Figure 4. Correlation between the intensity of monogenoideans (D. cycloancistrium and $D$. cycloancistrioides) and body weight and length of Arapaima gigas $(\mathrm{n}=54)$ in fish farms from the eastern Amazon, Brazil.

\section{DISCUSSION}

The rapid expansion of aquaculture has provided opportunities for increased parasitic infections and additional exposure to emerging disease etiologies in fish. The I. multifiliis is one of the most pathogenic protozoa in fish because it has no host specificity. Therefore, it is a major problem for fish farming worldwide (Dickerson, 2006; Eiras et al., 2010). Ichthyophthiriasis occurs mainly when there are changes in the temperature (Eiras et al., 2010). In Amazon variation in the temperature hardly occurs. However, the mean temperature is above $30^{\circ} \mathrm{C}$, 
so any other factor that can stress fish in this temperature can favor this parasite. Usually, I. multifiliis appears mainly in fish kept under high stocking densities and stressful conditions, due to the low level of dissolved oxygen in the water (Martins et al., 2002; Dickerson, 2006). Thus, knowledge of the ecological relationships among the parasites, their hosts and the environment in which they live is extremely important to avoid economical losses (Lizama et al., 2007b).

Infection by I. multifiliis occurred in A. gigas from the three studied fish farms. However, higher levels of infection occurred in one of the fish farms which showed low levels of oxygen and excess organic matter in the water of the culture pond. In the A. gigas gills the number of I. multifiliis showed a highly positive correlation with the weight and total length of fish, which indicates an increase of parasitism with the growth of the fish. This increase may be due to the cumulative process, since the gills increase their surface area proportionally to the growth of fish (Alves et al., 2000; Lizama et al., 2007a, b). Thus, there is also a proportional increase in habitat for reproduction of this protozoan which has direct transmission. In addition, I. multifiliis showed an aggregated pattern of distribution in A. gigas. Parasite aggregation is common in fish (Rohde et al., 1995), and has important implications for the population and evolutionary dynamics of the parasite and its host.

Monogenoidea parasites are common both in fish from natural environment as in fish from cultures (Thatcher, 2006; Eiras et al., 2010) which serve as bioindicators (Madi and Ueta, 2009; Kaouachi et al., 2010). They are highly pathogenic parasites that attach to the gills, a vital organ in fish. Overall, they have a high degree of host specificity, as it is the case of the monogenoideans Dawestrema Price and Nowlin, 1967. In this study, D. cycloancistrium and D. cycloancistrioides were the monogenoideans found in the gills of the examined A. gigas. Similarly, these parasites have been described in the gills of this same host farmed in the State of Amazonas, but with higher levels of prevalence and intensity (Araújo et al., 2009b). Infection rates by $D$. cycloancistrium and $D$. cycloancistrioides differed among the three investigated fish farms. The lowest rates of parasitism were found in the fish farm where a lower number of A. gigas were examined.
Marques and Cabral (2007) have demonstrated that even though a sampling smaller than 40 specimens does not influence the prevalence of parasites, it can lead to an underestimation of intensity and abundance.

In pirarucus of fish farms from the State of Amapá, the factor Kn correlated negatively with the number of $D$. cycloancistrium and D. Cycloancistrioides, which indicate a pathogenicity of these parasites in gills that had an aggregated pattern of distribution. However, an increase in body weight and length leads to a decrease in the intensity of these helminthes in the hosts' gills. Similarly, a negative correlation of Kn with the abundance of monogenoideans Cichlidogyrus sclerosus and Cichlidogyrus sp. in Oreochromis niloticus (Lizama et al., 2007a) and of $\mathrm{Kn}$ with the abundance of Monogenoidea Anacanthorus penilabiatus and Mymarothecium sp. in Piaractus mesopotamicus (Lizama et al., 2007b) has been reported. However, negative correlations for monogenoideans may result from host self-immunity to these helminthes over time (Lizama et al., 2007a). Therefore, the study of factors influencing the host-parasite relationships has been gaining the interest of fish parasitologists in recent years.

In this study, no monogenoideans were found in the gills of A. gigas from fish farms with a low level of oxygen and a high level of organic matter in the ponds. Although many monogenoideans species have a predilection for polluted environments (Galli et al., 2001; Buchmann and Brescani, 2006; Madi and Ueta, 2009), the occurrence of some is negatively influenced by pollution (Dzikowski et al., 2003; Kaouachi et al., 2010). Therefore, it is possible that monogenoideans D. cycloancistrium and $D$. cycloancistrioides are sensitive to polluted environments. Nevertheless, additional studies are needed for better conclusions.

Three species of Acanthocephala, genus Polyacanthorhynchus Travassos, 1926 are known in South America: Polyacanthorhynchus macrorhynchus Diesing, 1856, P. rhopalorhynchus Diesing, 1851 and P. caballeroi Diaz-Ungria and Rodrigo,1960 (Amin and Dezfuli, 1995; Aloo and Dezfuli, 1997). A fourth specie of parasite attacking several freshwater fish in Africa is P. kenyensis Schmidt and Canaris (1967), (Amin and Dezfuli, 1995; Aloo and Dezfuli, 1997; Aloo, 2002). In 
Brazil, only P. macrorhynchus (Balis, 1927; Machado-Filho, 1947; Thatcher, 2006) and $P$. rhopalorhynchus (Thatcher, 2006; Santos et al., 2008) have been documented parasitizing freshwater fish, namely a natural population of A. gigas.

Usually the acanthocephalan species are endohelminthes with a heterogeneous life cycle involving two hosts. The intermediate host is usually a micro-crustacean (ostracod, copepod, amphipod or isopod) and the definitive host, a fish (Aloo, 2002; Thatcher, 2006; Eiras et al., 2010). In the definitive host, the abundance of endohelminthes depends on its eating habits and therefore, carnivorous fish have higher infection rates than omnivore fish (Pavanelli et al., 2004; Ahmed et al., 2007; Takemoto et al., 2009), since the transference of these adult endohelminthes among the host fish is also possible (Nickol, 2006). Reports of outbreaks in farmed fish due to acanthocephalan infection are rare (Eiras et al., 2010), since these endohelminthes are more frequent in natural populations of fish, where there is a constant presence of intermediate hosts, and, consequently, of infectants forms.

Acanthocephalans $P$. macrorhynchus had an aggregated pattern of distribution, and until the present moment, these parasites were found only in A. gigas cultured in a fish farm in the State of Amapá, eastern Amazon. These helminthes had not been reported in A. gigas from other cultures in Brazil. The prevalence, mean intensity and abundance of $P$. macrorhynchus were similar to the ones described by Santos et al. (2008) for this same host from the Araguaia River (MT) parasitized by $P$. rhopalorhynchus. Even though the source of contamination by these endohelminthes in $A$. gigas has not been identified, it may be a result of the harvesting of the water supply, which facilitates the access of intermediate hosts, such as crustaceans living in the ponds. However, it is also possible that these fish were already parasitized by $P$. macrorhynchus since the fingerling stage.

\section{ACKNOWLEDGEMENTS}

The authors thank to CNPq by for supporting this project (\# 578159/2008-2) and for the grant to M. Tavares-Dias (PQ).

\section{REFERENCES}

AHMED, M.S.; IQBAL, T.; MAHMOOD, A. et al. Helminth parasites of some freshwater fishes. Punjab Univ. J. Zool., v.22, p.1-6, 2007.

ALOO, P.A. A comparative study of helminth parasites from the fish Tilapia zillii and Oreochromis leucostictus in Lake Naivasha and Oloidien Bay, Kenya. J. Helminthol., v.76, p.95102, 2002.

ALOO, P.A.; DEZFULI, B.S. Occurrence of cystacanths of Polyacanthorhynchus kenyensis larvae (Acanthocephala) in four teleostean fishes from a tropical lake, Lake Naivasha, Kenya. Folia Parasitol. v.44, p.233-238, 1997.

ALVES, D.R.; LUQUE, J.L.; PARAGUASSU, A.L. Ectoparasitas da tilápia nilótica Oreochromis niloticus (Osteichthyes: Cichlidae) da estação de piscicultura da UFRJ. Rev. Univ. Rural, Cienc. Vida, v.22, p.81-85, 2000.

AMIN, O.M.; DEZFULI, B.S. Taxonomic notes on Polyacanthorhynchus kenyensis (Acanthocephala: Polyacanthorhynchidae) from Lake Naivasha, Kenya. J. Parasitol., v.81, p.7679, 1995.

ARAÚJO, C.S.O; TAVARES-DIAS, M.; GOMES, A.L.S. et al. Infecções parasitárias e parâmetros sanguíneos em Arapaima gigas Schinz, 1822 (Arapaimidae) cultivados no estado do Amazonas, Brasil. In: TAVARES-DIAS, M. (Org.). Manejo e Sanidade de peixes em cultivo. Macapá: Embrapa Amapá, 2009a. p.389-424.

ARAÚJO, C.S.O.; GOMES, A.L.; TAVARES-DIAS M. et al. Parasitic infections in pirarucu fry, Arapaima gigas Schinz, 1822 (Arapaimatidae) kept in a semiintensive fish farm in central Amazonia, Brasil. Vet. Arhiv, v.79, p.499-507, 2009b.

BAYLIS, H.A. Some parasitic worms from Arapaima gigas (teleostean fish) with a description of Philometra senticosa n. sp. (Filarioidea). Parasitology, v.19, p.35-47, 1927.

BUCHMANN, K.; BRESCANI, J. Monogenoidea (Phylum Platyhelminthes). In: WOO, P.T.K. (Ed.). Fish diseases and disorders. King's Lyn, UK: Biddles, 2006. p.297-344.

BUSH, A.O.; LAFFERTY, K.D.; LOTZ, J.M. et al. Parasitology meets ecology on its own terms: Margolis et al. Revisited. J. Parasitol., v.83, p.575-583, 1997. 
DICKERSON, H.W. Ichthyophthirius multifiliis and Cryptocaryon irritans (Phylum Ciliophora). In: WOO, P.T.K. (Ed.). Fish diseases and disorders. King's Lyn, UK: Biddles, 2006. p.116-1532.

DZIKOWSKI, R.; PAPERNA, I.; DIAMANT, A. Use of fish parasite species richness indices in analyzing anthropogenically impacted coastal marine ecosystems. Helgoland Marine Res., v.57, p.220-227, 2003.

EIRAS, J.C.; TAKEMOTO, R.M.; PAVANELLI, G.C. Métodos de estudo e técnicas laboratoriais em parasitologia de peixes. 2.ed. Maringá:Eduem, 2006. $199 \mathrm{p}$.

EIRAS, J.C.; TAKEMOTO, R.M; PAVANELLI, G.C. Diversidade dos parasitos de peixes de água doce do Brasil. Maringá: Clichetec, 2010. 333p.

GALLI, P.; CROSA, G.; MARINIELLO, L. et al. Water quality as a determinant of the composition of fish parasite communities. Hydrobiologia, v.452, p.173-179, 2001.

KAOUACHI, N.; BOUALEEG, C.; BENSOUILAH, M. et al. Monogenean parasites in sparid fish (Pagellus genus) in eastern Algeria coastline. Afr. J. Microbiol. Res., v.4, p.989-993, 2010.

KRITSKY, D.C.; BOEGER, W.A.; THATCHER, V.E. Neotropical Monogenea. 7. Parasites of the pirarucu, Arapaima gigas (Cuvier), with descriptions of two new species and redescriptions of Dawestrema cycloancistrium Prince and Nowlin, 1967 (Dactylogyridae: Ancyrocephaline). Proc. Biol. Soc. Wash., v.98, p.321-331, 1985.

LE-CREN, E.D. The length-weight relationship and seasonal cycle in gonadal weight and condition in the perch (Perca fluviatilis). J. Anim. Ecol., v.20, p.201219, 1951.

LIZAMA, M.A.P.; TAKEMOTO, R.M.; RANZANIPAIVA, M.J.T. et al. Relação parasito-hospedeiro em peixes de piscicultura da região de Assis, estado de São Paulo. Brasil. 1. Oreochromis niloticus (Linnaeus 1957). Acta Sci. Biol. Sci., v.29, p.223-231, 2007 a.

LIZAMA, M.A.P.; TAKEMOTO, R.M.; RANZANIPAIVA, M.J.T. et al. Relação parasito-hospedeiro em peixes de pisciculturas da região de Assis, Estado de São Paulo, Brasil. 2. Piaractus mesopotamicus (Holmberg, 1887). Acta Sci. Biol. Sci., v.29, p.437445, $2007 \mathrm{~b}$.

MACHADO-FILHO, D.A. Revisão do gênero Polyancanthorhynchus Travassos, 1920 (Acanthocephala, Rhadinorhynchidae). Rev. Brasil. Biol., v.7, p.195-201, 1947.
MADI, R.R.; UETA, M.T. O papel de Ancyrocephalinae (Monogenea: Dactylogyridae), parasito de Geophagus brasiliensis (Pisces: Cichlidae), como indicador ambiental. Rev. Bras. Parasitol. Vet., v.18, p.38-41, 2009.

MARTINS, M.L.; MORAES, F.R.; BOZZO, F.R. et al. Recent studies on parasitic infections of freshwater cultivated fish in the state of São Paulo, Brazil. Acta Sci. Biol. Sci, v.24, p.981-985, 2002.

MINISTÉRIO DA PESCA E AQUICULTURA MPA. Boletim estatístico da pesca e aquicultura Brasil 2010. Brasília, DF, 2012. 128p.

NICKOL, B.B. Phylum Acanthocephala. In: WOO, P.T.K. (Ed.). Fish diseases and disorders. King's Lyn, UK: Biddles, 2006. p.444-465.

NÚÑEZ, J.; CHU-KOO, F.; BERLAND, M. et al. Reproductive success and fry production of the pauche or pirarucu, Arapaima gigas (Schinz), in the region of Iquitos, Perú. Aquaculture Res., v.42, p.815-822, 2011.

ONO, E.A.; ROUBACH, R.; PEREIRA, M.F. Pirarucu production - advances in central Amazon, Brazil. Global Aquacul. Adv., v.6, p.44-46, 2003.

ONO, E.A.; HALVERSON, M.R.; KUBITZA, F. Pirarucu - O gigante esquecido. Panorama Aquicul., v.14, p.14-25, 2004.

PAVANELLI, G.C.; MACHADO, M.H.; TAKEMOTO, R.M. et al. Helminth fauna of fishes: diversity and ecological aspects. In: THOMAZ, S.M.; AGOSTINHO, A.A.; HAHN, N.S. (Eds.). The upper Paraná River and its floodplain: physical aspects, ecology and conservation. Leiden: Backhuys Publishers, 2004. p.309-329.

PEREIRA-FILHO, M.; ROUBACH, R. Pirarucu, Arapaima gigas. In: BALDISSEROTTO, B.; GOMES, L.C. (Orgs). Espécies nativas para piscicultura no Brasil. Santa Maria: Editora UFSM, 2010. p.27-56.

PORTES-SANTOS, C.P.; MORAVEC, F.; VENTURIERI, R. Capillostrongyloides arapaimae sp. n. (Nematoda: Capillariidae), a new intestinal parasite of the arapaima Arapaima gigas from the Brazilian Amazon. Mem. Inst. Oswaldo Cruz, v.103, p.392-395, 2008.

MARQUES, B.F.; CABRAL, H.N. Effects of sample size on fish parasite prevalence, mean abundance and mean intensity estimates. J. Appl. Ichthyol., v.23, p.158-162, 2007.

ROHDE, K.; HAYWARD, C.; HEAP, M. Aspects of the ecology of metazoan ectoparasites of marine fishes. Int. J. Parasitol., v.25, p.945-970, 1995. 
RÓZSA, L.; REICZIGEL, J. MAJOROS, G. Quantifying parasites in samples of hosts. $J$. Parasitol., v.86, p.228-232, 2000.

SANTOS, S.M.C.; CECCARELLI, P.C.; LUQUE, .L. Helmintos parasitos do pirarucu, Arapaima gigas (Schinz, 1822) (Osteoglossiformes: Arapaimidae), no Rio Araguaia, estado de Mato Grosso, Brasil. Rev. Bras. Parasitol. Vet., v.17, p.171-173, 2008.

TAVARES-DIAS, M.; MARTINS, M.L.; MORAES, F.R. Fauna parasitária de peixes oriundos de pesquepague do município de Franca, São Paulo, Brasil. I Protozoários. Rev. Bras. Zool., v.18, p.67-79, 2001a.
TAVARES-DIAS, M.; MORAES, F.R.; MARTINS, M.L. et al. Fauna parasitária de peixes oriundos de pesque-pagues do município de Franca, São Paulo, Brasil. II. Metazoários. Rev. Bras. Zool, v.18, p.81-95, 2001b.

TAKEMOTO, R.M.; PAVANELLI, G.C.; LIZAMA, M.A.P. et al. Diversity of parasites of fish from the upper Paraná River floodplain, Brazil. Braz. J. Biol., v.69, p.691-705, 2009.

THATCHER, V.E. Amazon fish parasites. 2.ed. Moscow, Sofia: Pensoft Publishers, 2006. 508p.

ZAR, J.H. Biostatistical analysis. New Jersey: Prentice-Hall, 1999. 663p. 